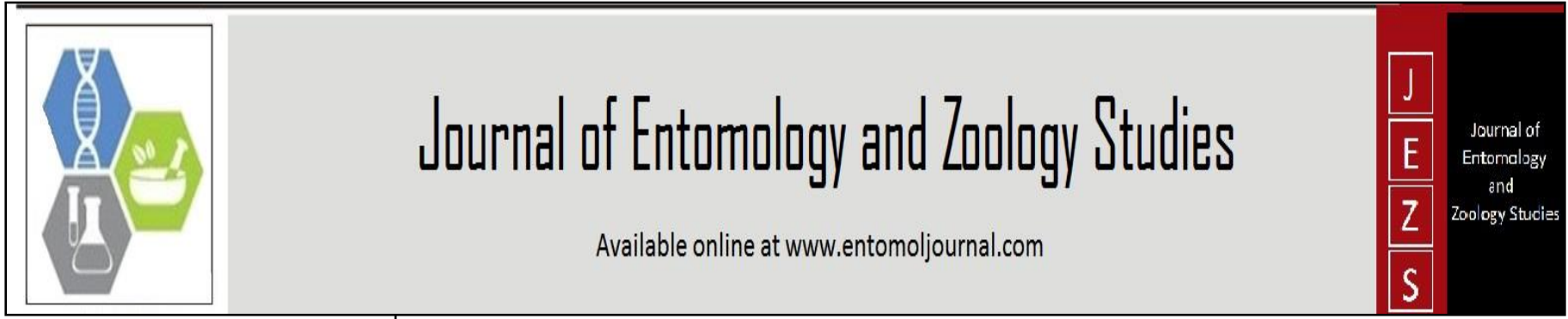

E-ISSN: 2320-7078

P-ISSN: 2349-6800

JEZS 2018; 6(1): 910-917

(C) 2018 JEZS

Received: 06-11-2017

Accepted: 07-12-2017

Md. Mer Mosharraf Hossain

Associate Professor, Department of Fisheries and Marine

Bioscience, Jessore University of Science and Technology, Jessore, Bangladesh

Jannatul Ferdoushi

Department of Fisheries and

Marine Bioscience, Jessore

University of Science and

Technology, Jessore, Bangladesh

Ariful Haque Rupom

Department of Fisheries and

Marine Bioscience, Jessore

University of Science and

Technology, Jessore, Bangladesh

\section{Biology of anchor worms (Lernaea cyprinacea)}

\author{
Md. Mer Mosharraf Hossain, Jannatul Ferdoushi and Ariful Haque \\ Rupom
}

DOI: https://doi.org/10.22271/j.ento.2018.v6.i1m.3047

\begin{abstract}
Lernaea cyprinacea (Anchor worm), a parasitic cyclopoid copepod is found to parasitize in the broodstock, nursery, and culture system in the freshwater aquaculture ponds and hatchery of Jessore regions. Lernea sp. infestations found in major carps (Indian \& Chinese), minor barbs, catfish and perches. Total eight hundred (800) fish of different host fish species were collected during (2016-2017); conducted gross biology (sexual dimorphism: female larger; reproductive features: gonochoric or sexual; food habits: carnivore (body fluids); reproduces at $>15 \mathrm{C}$; fish are the intermediate and definitive hosts), invasion pattern (highest invasion $(98 \%)$ to mosquitofish and lowest $(13 \%)$ to shing) and life-cycle (metamorphism; direct life cycle can take from 18 to 25 days at $26-28^{\circ} \mathrm{C}$, mature female within 24 hours released egg produce batches of up to 250 juveniles (nauplii) $>25^{\circ} \mathrm{C}$. But the female remains parasitic, attached to the current host or moving to another fish and adult males die within 24 hours). This study recorded highest prevalence $72 \%$ with $L$. cyprinacea in January to March, while the lowest prevalence (8\%) recorded during April-June. Lernaea infestation includes the skin, fins, gills, and oral cavity. Fish can survive with Lernaea infestation, but chronic conditions frequently result in poor growth and fish become more susceptible to secondary infection by bacteria and fungus which ultimately kill the fish.
\end{abstract}

Keywords: Anchor worm, biology, invasion pattern, life-cycle, prevalence and diseases

\section{Introduction}

Bangladesh is in the 4th position in fresh water aquaculture production after China, India and Myanmar. Aquaculture production in Bangladesh mainly depends on artificial seed production by hatchery by induced breeding. Quality seed and quality brood are the crucial needs for aquaculture in Bangladesh. However, seedling and brood fish have been affected by some emerging parasites/pathogens (Argulusiosis, Lernaeaosis, Saprolegniasis and other bacterial sp.). Control and prevention of those diseases are urgent need for sustainable aquaculture in Bangladesh.

For the last three years, one kind of mosquito fish (supposed) have invaded in greater Jessore regions and distributed all over the brood ponds specially carps or other fish in the region, which is the major seed production regions (90\% hatchery situated in Jessore regions in Bangladesh). This invasive fish species showed very strong adaptability and have been propagated in the hatcheries and consuming food originally for carps. Basis on the initial field visit and epideiological survey, fish farmers currently cannot control this fish at any cost. Furthermore, the fish species carry parasitic copepod Lernaea sp. (anchor worm) and several other ecto-parasites. The parasites are propagated in brood rearing ponds, hatcheries tanks and consequently affecting carp seedlings. Due to the invasion of the mosquito fish and propagation of anchor worms, 29 hatcheries out of 69 hatcheries in Jessore regions stopped or closed their operations. So, Lernaea and mosquito fish highly specialized drug resistant with a very wide range of aquatic hosts, and represent emerging issues or one of the most severe threats to cultured fresh water fish.

The entire water area of the Jessore region $\left(22^{\circ} 35^{\prime}-23^{\circ} 10^{\prime} \mathrm{N}\right.$ latitude and $88^{\circ} 90^{\prime}-89^{\circ} 35^{\prime} \mathrm{E}$ longitude in Fig. 1 in Bangladesh supports the potential finfish hatchery operation and seed supply to the whole country. The lernaeid copepod Lernaea cyprinacea Linnaeus, 1758, often called the anchor worm, is a parasite of freshwater fishes in various regions of the world ${ }^{[1,2]}$. The copepod is known as a pathogen of cultured and aquarium fishes ${ }^{[2,3]}$. In Japan, various studies on the biology of L. cyprinacea have been conducted to date since the work of Ishii (1915) ${ }^{[4]}$ who recorded it as Lerneocera cyprinacea. The species was later described by Leigh-Sharpe (1925) as a new species, Lernaea elegans from the Japanese eel Anguilla japonica in central Japan, which was subsequently regarded by Harding (1950) ${ }^{[5]}$ as a junior

\section{Correspondence}

Associate Professor, Department of Fisheries and Marine ioscience Jessore University of Science and Technology Jessore Sadar, Jessore, Bangladesh 
synonym of L. cyprinacea. Taxonomy: The larval stages (nauplii) and juvenile stages (copepodites), males, and unfertilized females of lernaeid copepods have typical cyclopoid features. The fertilized female undergoes a radical transformation, and becomes an attached worm-like parasite, with few noticeable arthropod features [6, 7, 8]. Kingdom: Animalia; Phylum: Crustacea; Class: Copepoda; Order: Cyclopoida; Family: Lernaeidae; Genus: Lernaea; Species: Lernaea cyprinacea; Common Names: Anchor-worm; Anchor parasite; Synonymy - Adult females of Lernaea cyprinacea, and other lernaeids, show great plasticity in the shape of the holdfast, a principal taxonomic character, according to the host species and the site of attachment. Several previously recognized species have been shown experimentally to be variants in the morphology of $L$. cyprinacea on different hosts ${ }^{[1,9,10]}$.

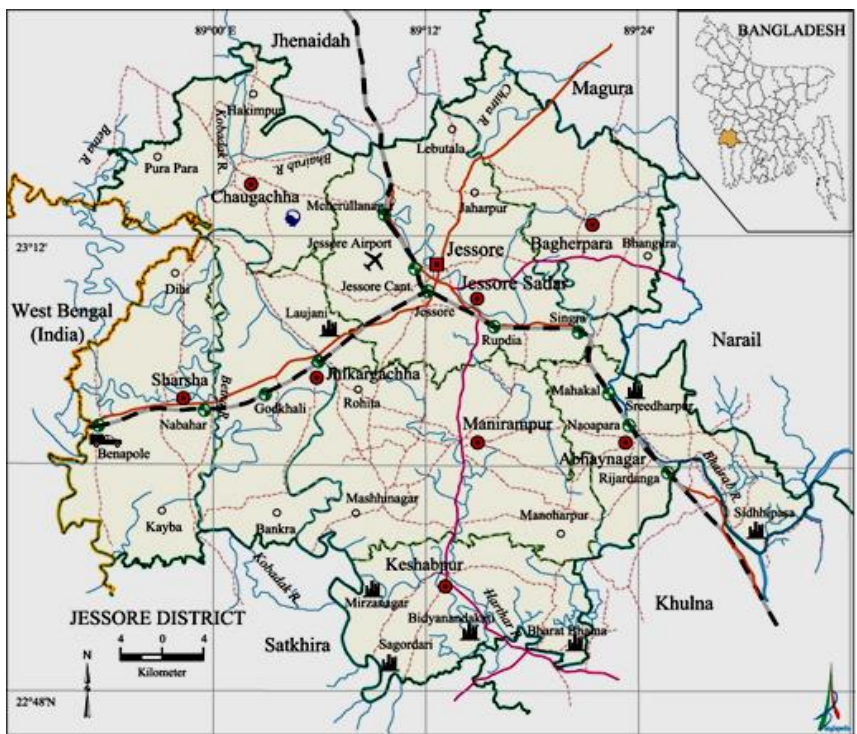

Fig 1: Jessore regions, the major finfish hatchery for production of fish seeds in Bangladesh.

In Bangladesh, none of the chemicals tested was effective on fish heavily infected with Lernaea sp. (anchor worm) or mosquito fish. Fish are assumed to, or are known to, respond immunologically to numerous other parasitic infections. These include: Cryptocaryon irritans, Myxosoma cerebralis, Gyrodactylus bullatarudis, Dactylogyrus vastator, Ligula intestinalis, Diphyllobothrium, Anguillicola crassus. However, the precise role of the immune system in these infections or immunopathology has yet to be determined. In general, there are little antibody and cell-mediated responses during early Lernaea infections because the parasite antigenically mimics host tissues and depressed the innate nonspecific cytotoxicity of leukocytes. The extent and the mechanism of host tissue mimicry or immunodepression by parasites, presumably to avoid or reduce the host immune response, are both fascinating and in need of more careful study. In this research project, we studied the biology; transmission factors and dynamics of anchor worms in brood stock ponds and hatchery ponds to find the effective measures to control the fish and the infection with the anchor worms. In this research project we studied the biology of anchor worms to find the best way to control of anchor worms.

\section{Materials and methods}

2.1 Environment, Parasites, experimental species, visual and microscopic observations:

This study was done during the period of January 2016 to July 2017 supported by the Department of Fisheries and Marine Bioscience (FMB), Jessore University of Science and Technology (JUST). Technical supports were obtained from specially hatchery owners of finfish at Jessore regions of Jessore. Live carp infected with Lernaea cyprinacea of Rohu (Labeo rohita), Catla (Catla catla), Mrigal (Cirrhinus mrigala), Ctenopharyngodon idellus (Grass carp), Hypophthalmichthys molitrix (Silver carp), Hypophthalmichthys nobilis (Bighead carp), Bata (Labeo bata) and Common carp (Cyprinus carpio) were randomly collected from the brood pond kept in 08 (eight) small water bodies (1.5 decimal pond, Fig. 1) in the vicinity of the university. A total number of 800 (eight hundred) fish of eight species groups; 100 (hundred) fishes from each species were kept in a pond and observed for crustacea: copepod infestation. One pond was used for control, stocked 200 fishes with eight species groups in 03 decimal ponds (Fig. 2). The water quality parameters were monitored in pond environmental systems (Table 1). The infected and healthy fishes were regularly collected and examined for biology, prevalence and distributions of Lernaea in pond environment and laboratory during this experimental period. The parasites were carefully removed from the hosts with the help of fine forceps and placed in pertussis containing distilled water in the laboratory. Specimens were examined under the photography microscope (AxioCam ERc 5s with Axio Vision driver, Carl Zeiss, Germany) in Fig. 3.

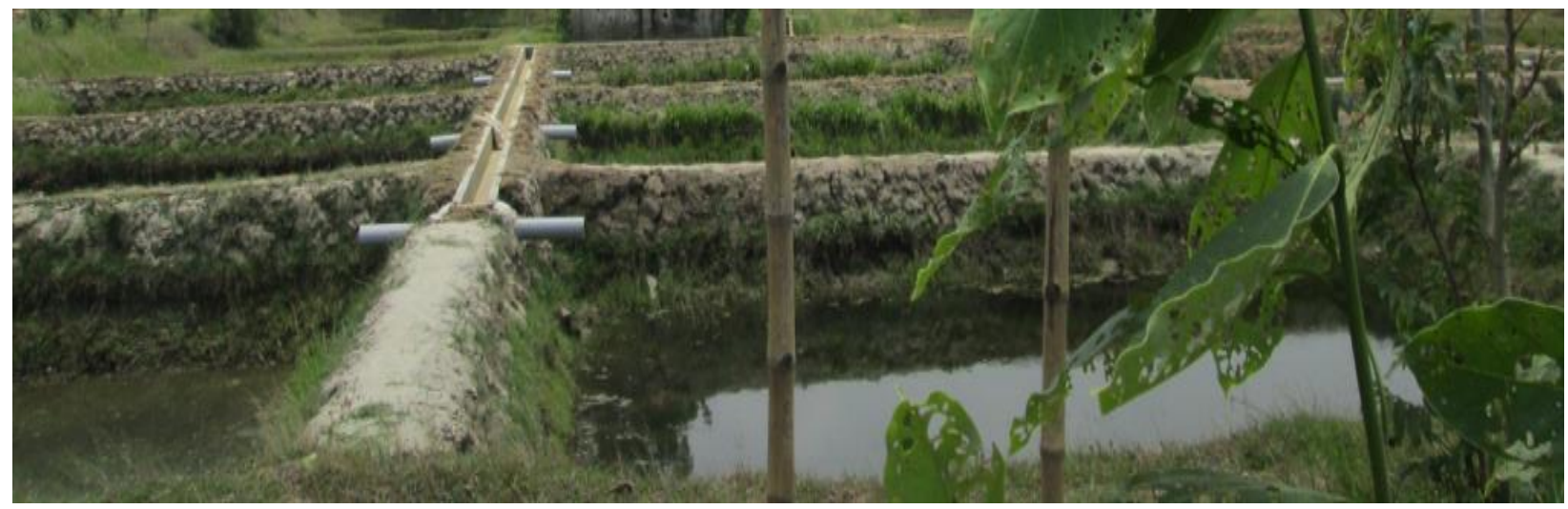

Fig 2: Experimental fish ponds to observe the biology of Lernaea cyprinacea (Anchor worms) in field lab of FMB dept. at JUST. 


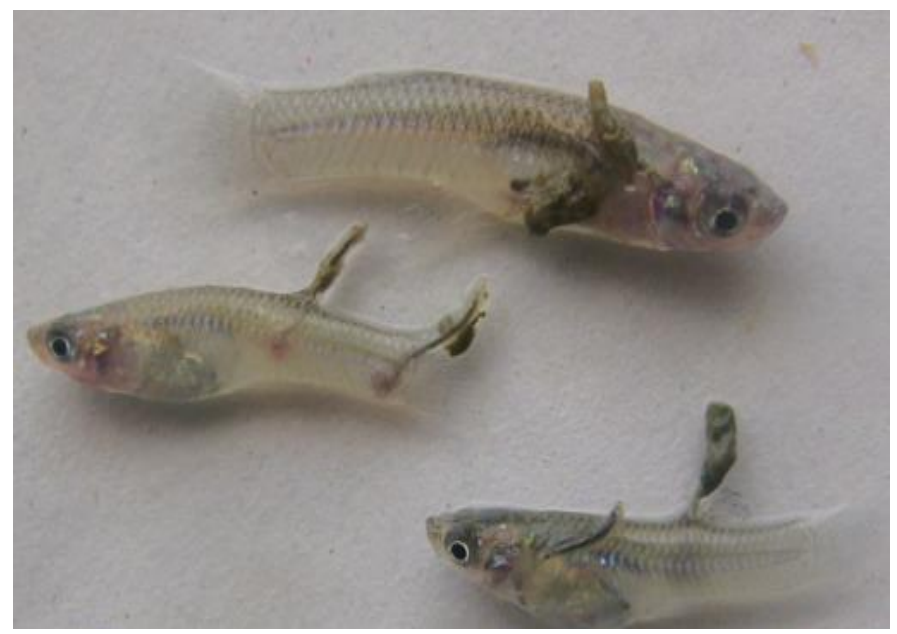

Infested mosquitofish

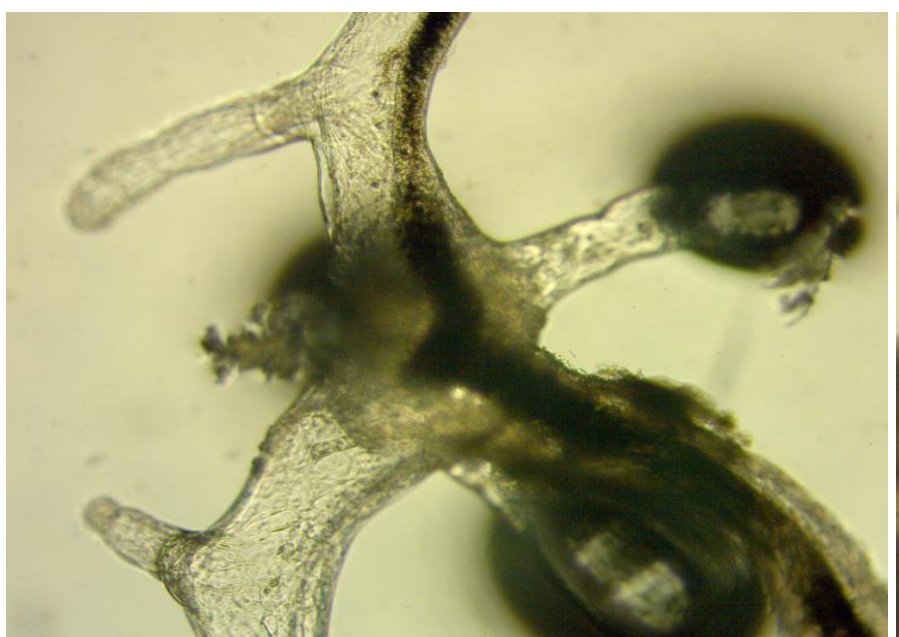

Anchoring device

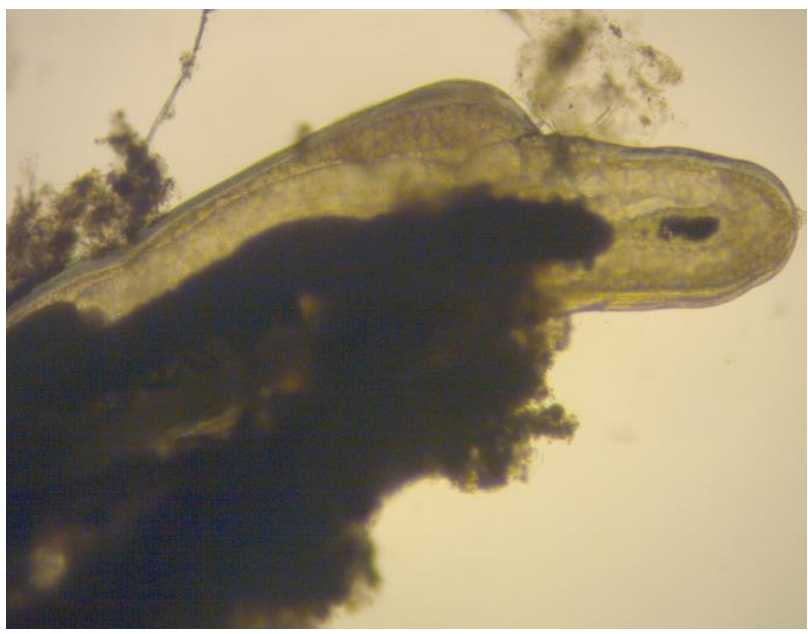

Egg sac

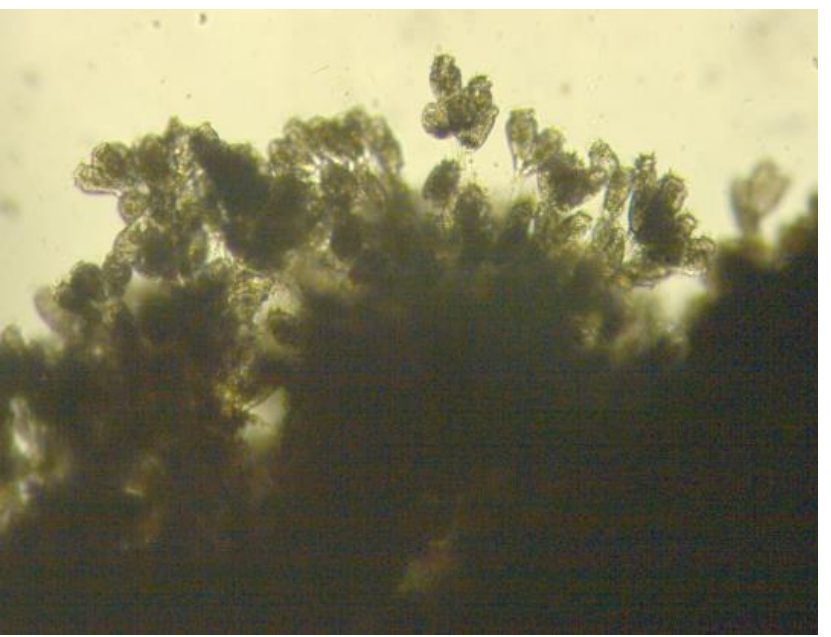

Mature eggs

Fig 3: Mosquitofish (Gambusia affinis) infected with anchor worms and examined under photography microscope (anchoring device and egg sac)

Table 1: The water quality parameters in experimental pond culture systems.

\begin{tabular}{|c|c|c|c|c|c|c|}
\hline & Parameters & Unit & Optimal Range & Experimental Pond Complexes & Carp Brood Pond & Methods \\
\hline 1 & $\mathbf{p H}$ & & $\mathbf{6 . 5 0 - 9 . 0}$ & $\mathbf{8 . 3 9}$ & $\mathbf{7 . 8 1}$ & Membrane Electrode \\
\hline 2 & TDS & $\mathrm{mg} / \mathrm{L}$ & 1000 & 220 & 270 & Conductivity \\
\hline 3 & Total Alkalinity & $\mathrm{mg} / \mathrm{L}$ & 100 & 227.38 & 170.53 & Titrimetric \\
\hline 4 & Chloride & $\mathrm{mg} / \mathrm{L}$ & 600 & 17.00 & 0.17 & Mohr's Titration \\
\hline 5 & Ammonia & $\mathrm{mg} / \mathrm{L}$ & 0.20 & 0.14 & 0.03 & Cadmium Reduction \\
\hline 6 & Nitrate & $\mathrm{mg} / \mathrm{L}$ & 100 & 0.04 & 0.001 & Azide \\
\hline 7 & Nitrite & $\mathrm{mg} / \mathrm{L}$ & 0.03 & 0.003 & 0.24 & Ascorbic Acid \\
\hline 8 & Phosphate & $\mathrm{mg} / \mathrm{L}$ & 6 & 0.30 & 0.007 & HG-AAS \\
\hline 9 & Arsenic & $\mathrm{mg} / \mathrm{L}$ & 0.05 & 0.016 & 27.09 & Flame-AAS \\
\hline 10 & Iron & $\mathrm{mg} / \mathrm{L}$ & 0.30 & $<0.10$ & $<0.02$ & Flame-AAS \\
\hline 11 & Calcium & $\mathrm{mg} / \mathrm{L}$ & 100 & 26.52 & $<0.06$ & Flame-AAS \\
\hline 12 & Copper & $\mathrm{mg} / \mathrm{L}$ & 1.0 & $<0.02$ & $<0.03$ & Flame-AAS \\
\hline 13 & Zinc & $\mathrm{mg} / \mathrm{L}$ & 10.00 & $<0.06$ & $<0.02$ & Flame-AAS \\
\hline 14 & Lead & $\mathrm{mg} / \mathrm{L}$ & 0.05 & $<0.03$ & Flame-AAS \\
\hline 15 & Cadmium & $\mathrm{mg} / \mathrm{L}$ & 0.005 & $<0.02$ & & $<$ \\
\hline
\end{tabular}

\section{Result}

\subsection{Invasion Pattern}

Parasitic copepods, isopods, argulids etc. parasitising the gills and skin of fishes, they often pose a great problem in fish nurseries and culture systems in Bangladesh. No systematic works were conducted on crustacean parasites of fishes of Bangladesh. But there are several reports particularly of
Argulus (fish louse) infesting nurseries and other cultural fishes. Lernaea (anchor worm) infects a wide range of teleost fish in different seasons (Fig.3). Highest invasion (98\%) to mosquitofish and lowest (13\%) to shing in summer and highest invasion $(69 \%)$ to mosquitofish and lowest invasion (3\%) to koi in winter season (Fig. 4). 


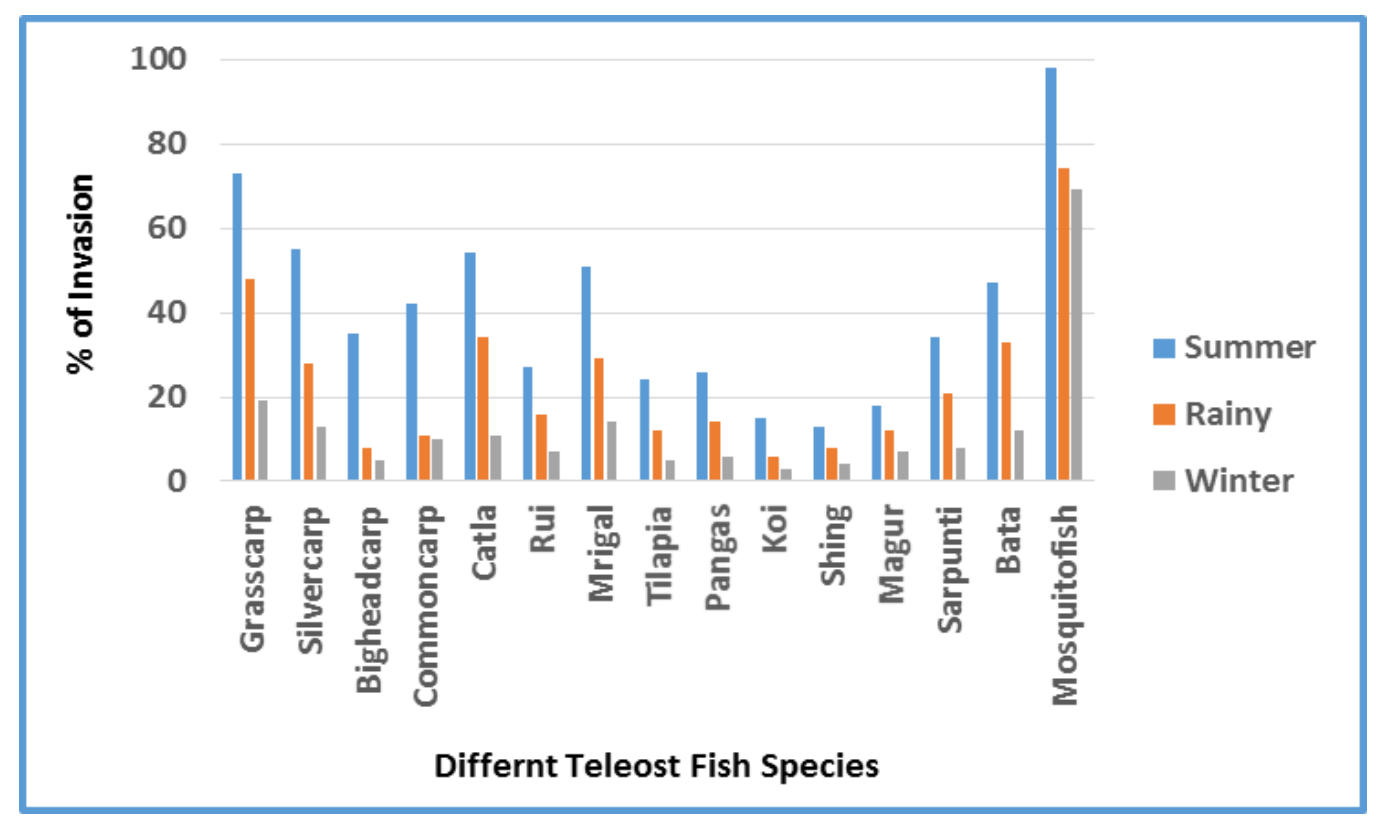

Fig 4: Seasonal invasion pattern of anchor worms to different teleost fish species in Bangladesh.

\subsection{Gross biology of anchor worms}

Biology of anchor worms observed under a fish pond culture system in FMB department and different fin fish hatchery at Jessore regions approximately since 2013. Anchor infested eight hundred (800) fish species regularly monitored and examine in central laboratory at FBM, JUST (Table 2). In this research, the age and longevity (life-span) of anchor worms in mature female was 5-6 months and 20 to $25 \mathrm{~mm}$ length (Table $3)$.

Table 2: Gross biology of anchor worms in Bangladesh

\begin{tabular}{|c|c|c|}
\hline Habitat environment & $:$ & Summer, rainy and winter \\
\hline Habitat regions & $:$ & Temperate, tropical and freshwater \\
\hline Aquatic biomes & $:$ & Ponds, lakes, rivers, streams and reservoirs \\
\hline Physical features & $:$ & ectothermic, heterothermic and bilateral symmetry \\
\hline Sexual Dimorphism & $:$ & Female larger \\
\hline Life cycle & $:$ & Metamorphism \\
\hline Behavior & $:$ & Parasite, motile and sedentary \\
\hline Communication and perception & $:$ & Visual, tactile and chemical \\
\hline Food habits & $:$ & Carnivore (body fluids) \\
\hline Impacts & $:$ & Causes or carries domestic animal disease \\
\hline
\end{tabular}

Table 3: Age and Growth of anchor worms.

\begin{tabular}{|c|c|c|}
\hline & Male & Female \\
\hline Minimum Adult Size (mm) & $1-2$ & $3-4$ \\
\hline Maximum Adult Size (mm) & $15-18$ & $20-25$ \\
\hline Typical Longevity (month) & $3-4$ & $5-6$ \\
\hline Maximum Longevity (month) & $5-6$ & $6-8$ \\
\hline
\end{tabular}

\subsection{Response to environmental fluctuations}

In this experiment since the 2013 we observed the ecology for 800 fish species from different fish groups in pond environment systems. This study addressed the survival and reproduction behavior ecology in which anchor worms showed the steady-state tolerance limits in response to gradual variations of an environmental factor to rapid fluctuations (Table 4).

Table 4: Response to environmental fluctuations of anchor worms.

\begin{tabular}{|c|c|c|c|c|c|}
\hline & \multicolumn{2}{|c|}{ For Survival } & \multicolumn{2}{c|}{ For Reproduction } & Comments (Optimum for Fish) \\
\hline & Minimum & Maximum & Minimum & Maximum & 15 to 35 \\
\hline Temperature $\left({ }^{\circ} \mathrm{C}\right)$ & $8-10$ & $30-38$ & 15 & $30-38$ & 0 to 5 \\
\hline Salinity $(\%$ o) & 0 & 15 & 0 & $7-8$ & 3.5 to 5.0 \\
\hline Oxygen (mg/l) & 0 & $6-7$ & 0 & $6-7$ & 6.5 to 8.5 \\
\hline $\mathrm{pH}$ & 2 & 11.5 & 2 & 10.5 & 25 to 30 \\
\hline Turbidity (cm) & 5 & $20-50$ & 5 & $20-50$ & (0.0 to 0.2$)$ \\
\hline Ammonia (mg N/L) & 0.0 & 3.0 & 0.0 & 2.5 & \\
\hline
\end{tabular}

\subsection{Reproduction}

This study showed that in the fourth copepodid stage, both sexes become sexually mature. In this free-swimming stage the female becomes fertilized and the male dies without developing further. The females seek their second host. Only females are visually seen (length ca. 10-12 mm). A hatched nauplius grows to the first copepodid which settles on a host fish. Males detach from the host after the opulation. This is where the females form their egg sacs. It reproduces at $>15$ C., stops the reproduction and overwinters at $<12 \mathrm{C}$ after $4-5$ generation changes (Table 5). 
Table 5: Under natural conditions, several generations occur in the course of one year. Throughout its development stages the different reproductive strategies were observed in its free-swimming stages of life.

\begin{tabular}{|c|c|}
\hline Reproductive Season & July-November (>15 C) \\
\hline Sexuality Mode(s) & Doiecious \\
\hline Fertilization Type(s) & Outcross-internal; or (Internal ); oviparous \\
\hline Reproductive Event per Year & 3 - to 4 times \\
\hline Reproductive features & $\begin{array}{l}\text { gonochoric/gonochoristic/dioecious } \\
\text { (sexes separate); sexual. }\end{array}$ \\
\hline Egg/Seed Form & brooded \\
\hline No of Eggs/Female & $250-340$ \\
\hline Larval/seed development periods (days) & 2 to 12 \\
\hline Male Maturation age (mths) & $4-5$ \\
\hline Female maturation age (mths) & $5-7$ \\
\hline
\end{tabular}

\subsection{Locomotion and Habitat}

This study showed the parasites usually live in freshwater habitats. The salinity of the water affects how well the copepod reproduces. "Sweet water" is the only possible environment for the Lernaea cyprinacea reproduction to be possible. This parasite was found in ponds with 0.071$1.6965 \% \mathrm{NaCl}$. All of the copepods were found in fresh-water and flood lakes only, never in saltier neighboring lakes. Fish those were used in this experiment are the intermediate and definitive hosts. Mainly these hosts are from the family Cyprinidae are parasitized by Lernaea cyprinacea. Many of these serve as intermediate as well as definitive hosts during heavy infestation. The parasite feeds on the internal tissues of the fish. It attaches to the gill chambers of the fish and parasitizes it externally. This parasite is a big threat because it lacks host specificity to such an extent that it can infect all freshwater fish and even frog tadpoles and salamanders (Table 6).

Table 6: Habitat and trophic status of anchor worms.

\begin{tabular}{|c|c|c|c|}
\hline & Locomotion & Habitat & Tropihic status \\
\hline Larvae & planktonic & freshwater; coarse woody debris; unstructured, stagnant & non-feeding \\
\hline Juvenile & parasite (nektonic host); planktonic & freshwater; coarse woody debris; unstructured, slow & parasite \\
\hline Adult & parasite (nektonic host) & freshwater; coarse woody debris; unstructured, fast & parasite \\
\hline
\end{tabular}

\subsection{Prevalence}

Approximately 100 fish from different fish species groups were examined in order to study the prevalence of anchor worm infestation. The sampling season may interfere with the estimation of the parasite abundance and prevalence, as the water temperature is related with the reproduction of anchor worms. It is clear that the prevalence of ectoparasitic infection changes with month. In winter season i.e., January-March it reaches its peak (Table 7).

Table 7: Prevalence of anchor worms in different months of the year

\begin{tabular}{|c|c|c|c|c|}
\hline Months & Crustacean & No. of hosts examined & No. of hosts infested & \% of Prevalence* \\
\hline April-June & L. cyprinacea & 25 & 2 & 8 \\
\hline July-September & L. cyprinacea & 25 & 5 & 20 \\
\hline October-December & L. cyprinacea & 25 & 11 & 44 \\
\hline January-March & L. cyprinacea & 25 & 18 & 72 \\
\hline
\end{tabular}

*Prevalence Rate of Disease = (n / Total population) x 100; Where $\mathrm{n}$ - All new \& preexisting cases of specific disease.

\subsection{Life Cycle of Lernaea}

Because Lernaea is a copepod and crustacean, it is related to crabs, lobsters, and shrimp, all of which have a multistage life cycle (Fig. 5). This study showed after a male and female parasite mate, the male dies and the female bores into the host tissue, eventually using a large anchor on her anterior ("head") end to permanently embed into the skin and muscle of the fish (Fig 5). The female matures into an adult and, within 24 hours, may begin to release eggs from a pair of sacs on its posterior ("back") end (Fig. 5). Each released egg hatches within 24-36 hours. Females are very prolific, and can produce batches of up to 250 juveniles (nauplii) every two weeks for up to 16 weeks at temperatures warmer than $25^{\circ} \mathrm{C}$. Newly hatched nauplii are free-living (not parasitic) and develop through three different naupliar stages in about 4 days. At that point they molt into the first copepodid stage, become parasitic, and attach to a host, often on the gills. Over the next 7 days, the parasite develops through five different "copepodid" stages. The copepodid stages typically are also found on the gills but are not permanently embedded in the tissue. Once in the final copepodid stage, the male detaches, but the female remains parasitic, attached to the current host or moving to another fish. Adult males die within 24 hours. In one study, the entire life cycle took approximately 18-25 days when fish were held at $29^{\circ} \mathrm{C}$. The optimal temperature range for Lernaea is $26-28^{\circ} \mathrm{C}$. If temperatures fall below $20^{\circ} \mathrm{C}$, juvenile Lernaea are unable to complete their development, and at $14^{\circ} \mathrm{C}$, females will not reproduce. However, adult females can overwinter on the fish host, producing eggs when water temperatures warm up in the spring. 


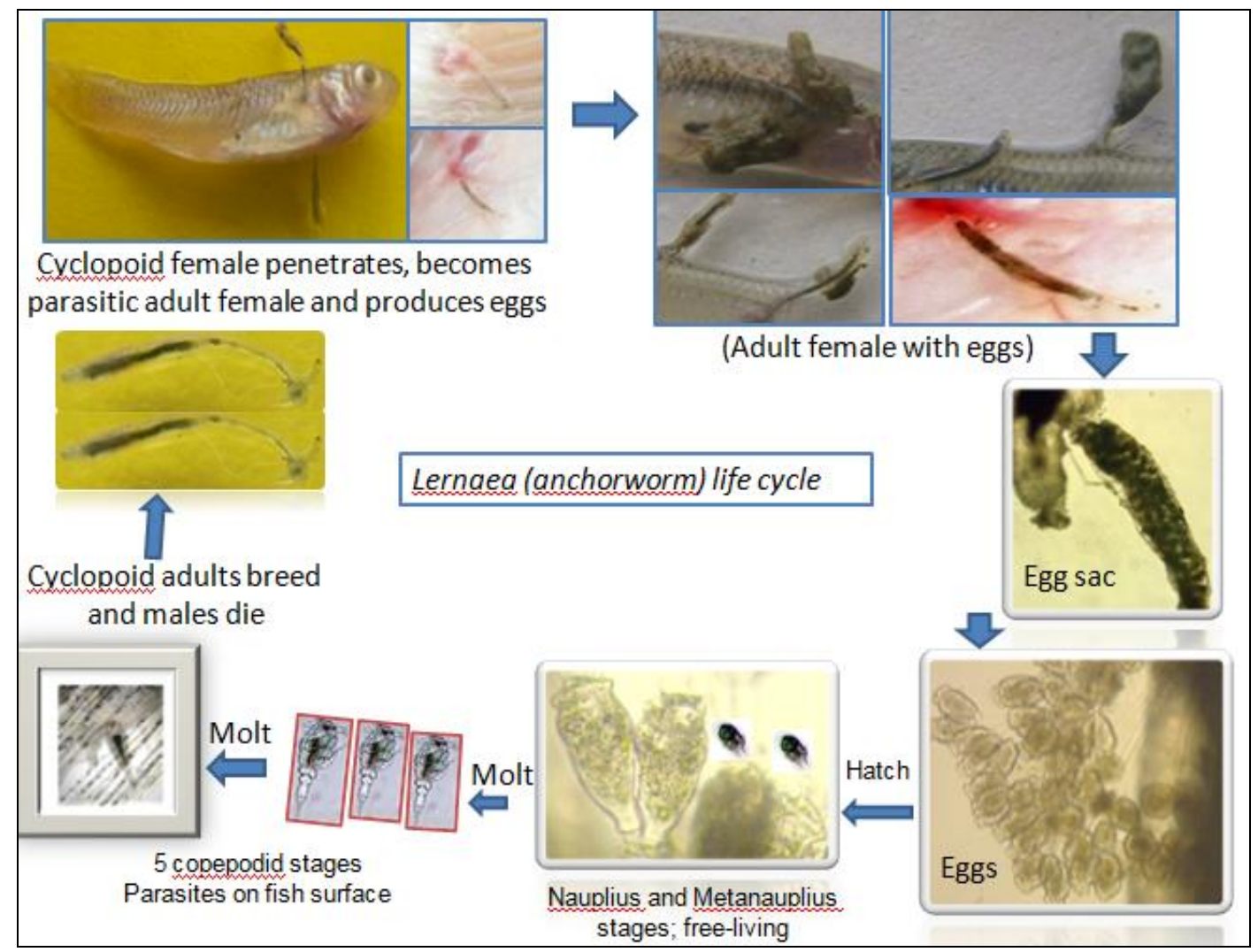

Fig 5: Lernaea (anchorworm) life cycle observed under photography microscope (AxioCam ERc 5s with Axio Vision driver, Carl Zeiss, Germany). The entire life cycle may take from 18-25 days at approximately 25-30oC (Hossain et al., 2013) ${ }^{[19]}$.

Figure 5 showed Lernaea cyprinacea eggs hatch in 1-3 days. When they hatch they are in the nauplius stage. This is a sixlegged elliptical larva. There are three nauplius stages. The first is the oval form, next is the without mouth or labrum form, and the third is a form with a single pair of furcal setae. After 4 to 16 days in the nauplius stage it metamorphoses into the first copepodid stage. After this metamorphosis, no further development occurs unless a host is found. The parasite then attaches to the host and undergoes further transformation. After attaching to the host, the larvae are not able to swim anymore because their appendages are reduced to short stumps and their setae are lost. The larvae spend some time on the host. They then molt. With this process they reform their appendages and acquire the ability to swim again and leave their intermediate host. The larva passes through 5 successive copepodid stages before the female attaches. In the fourth copepodid stage, both sexes become sexually mature. In this free-swimming stage the female becomes fertilized and the male dies without developing further. The females seek their second host. This is where the females form their egg sacs. About 14-28 days are needed to go from hatching to the production of egg sacks, depending on the temperature. In cold temperatures it could take up to a year to produce a new generation. Under natural conditions, however, several generations occur in the course of one year ${ }^{[19]}$.

\subsection{Transmission and food habits}

Crustaceans have various sensory receptors, mainly setae over the body. Photoreceptors are also generally present [20] such as: communication channels (visual, tactile and chemical); and perception channels (tactile and chemical). The present study explored the many kinds of fish are the intermediate and definitive hosts, primary diet (carnivore; eats body fluids). Mainly these hosts are from the family Cyprinidae; fish such as Carissus auratus, Anguilla japonica, Carassius carassius, Gobio gobio gobio and Cypinus carpio all are parasitized by Lernaea cyprinacea. Many fish serve as intermediate as well as definitive hosts during heavy infestation. The parasite feeds on the internal tissues of the fish. It attaches to the gill chambers of the fish and parasitizes it externally. These species are probably preyed on indirectly. Several of the larval stages die due to not reaching a suitable host.

\subsection{Disease in Fish Caused by Lernaea}

Common sites of Lernaea infestation include the skin, fins, gills, and oral cavity (Fig 6). Large numbers of lernaeids in copepodid stages can kill small fish by damaging their gills and making it hard for the fish to breathe. When female parasites attach to the fish, they burrow deep into the tissues and eventually embed an anterior anchor into the fish's body. Intense focal inflammation and hemorrhage can occur at the attachment site, making the area appear red and ulcerated. While an infection by small numbers of parasites isn't necessarily fatal, it is extremely irritating to the fish. Lernaea can cause intense inflammation, leading to secondary bacterial (e.g., Aeromonas hydrophila) and fungal infections. These secondary infections sometimes worsen and kill the fish. Larger numbers of parasites on the gill can interfere with respiration, causing death. Fish can survive with Lernaea infestation, but chronic conditions frequently result in poor growth and fish become more susceptible to secondary infection by bacteria and fungus which ultimately kill the fish [19]. 

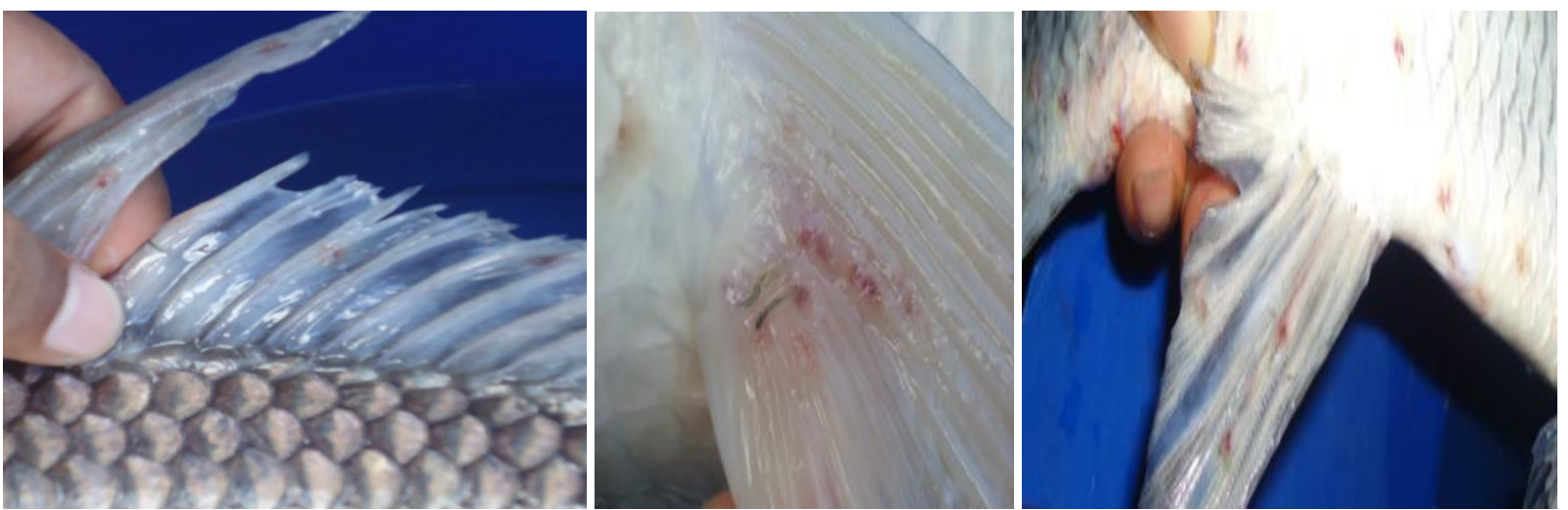

Fig 6: Portrait scale and Secondary infection in Ctenopharyngodon idellus (Grass carp) Grass carp caused by Lernaea cyprinacea

\section{Discussion}

Lernaea (anchor worm) was first described from Bangladesh by Hossain et al. (1978) that infects a wide range of teleost fish in different seasons. Lernaea cyprinacea (Anchor-Worm) was first described from Europe in 1745 under a trinomial name, and was described by Linnaeus in $1758^{[7,11]}$. This freshwater parasitic copepod infects a wide range of teleost

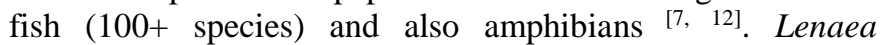
cyprinacea was first reported (as $L$. carassii) in North America from goldfish farms in $\mathrm{OH}$ (1929) and IA ${ }^{[13]}$. Wilson (1918) ${ }^{[8]}$ mentioned it in a global survey of the genus, but did not report it from this continent. Consequently, it has been widely spread throughout most of the world with ornamental and stocked fishes. Carassius auratus (Goldfish) may be likeliest vector ${ }^{[12,13]}$. It is probably native to Asia, including Japan, and has been introduced to mainland Europe, Africa, Australia, and North America ${ }^{[7,12,14,15]}$. Golder et al. (1987) ${ }^{[16]}$ and Rahman (1968) ${ }^{[17]}$ reported Lenaea cyprinacea in the fish farm likes tilapia, chital, khalisha and singhi in Bangladesh. Chandra et al. (2004) ${ }^{[18]}$ reported fish louse in the cultured major carps of Mymensingh.

Lernaea is unusual, however, as most common copepod species are free-living and do not cause disease. Although organisms belonging to this group have complex life cycles, they do not need to pass through an intermediate host; rather they can spread directly from fish to fish. This direct life cycle of anchor worms ${ }^{[19]}$ can take from 18 to 25 days to complete, and only a fish (or an amphibian) is necessary for the organism to develop from egg to mature adult. The lernaeid life cycle is similar whether the host is a fish or amphibian, but for simplicity this paper will focus on infections in fish. Different life stages during development live on and off the fish.

Crustaceans have various sensory receptors, mainly setae over the body. Photoreceptors are also generally present ${ }^{[20]}$ such as: communication channels (visual, tactile and chemical); and perception channels (tactile and chemical). This parasite is a big threat because it lacks host specificity to such an extent that it can infect all freshwater fish and even frog tadpoles and salamanders [12, 21]. The present study explored the many kinds of fish are the intermediate and definitive hosts, primary diet (carnivore; eats body fluids) during heavy infestation, several of the larval stages die due to not reaching a suitable host.

In this study showed the rejection of copepods Lernaea cyprinacea from skin of fishes or possible removal by the fish rubbing their bodies against the tanks was found in parts to a cellular and inflammatory responses, these responses occurring in attachment site of parasites. The cellular and inflammatory sites usually used by the different kinds of aquatic microbial components that causes secondary infection to fish ${ }^{[11,19,22,23,24]}$.

\section{Conclusion}

Lernaea cyprinacea can obviously become a problem for fish farmers. The parasite not only causes disfigurment in the fish, but it can also cause its death in cases of high infestation. The farmers are unable to sell these sick fish, and lose a great amount of money. In Bangladesh, the parasite has increased its number and spread to such an extent that it is a serious menace to fishing culture. It was first found to be causing damage to carps, in this case choking the mouth cavity, but it is also found in other fish, burrowing with the head under the scales. Countless pounds of fish have been destroyed because of this parasite. Wounds resulting from an infection with Lernaea should be closely monitored and optimal water quality and above recommended treatment should be maintained for the duration of treatment to minimize risk of secondary bacterial and fungal infection. Interestingly, there is evidence suggesting that successfully treated fish may become resistant to future infections with Lernaea. Quarantine and screening of incoming fish are highly recommended to avoid to introduction of the parasite.

\section{Acknowledgment}

Special thanks to hatchery owners, technician of finfish hatchery at Jessore regions and the Department of Fisheries and Marine Bioscience, Jessore University of Science and Technology.

\section{References}

1. Kabata Z. Parasitic copepoda of British fishes. London Ray Soc. 1979, 468.

2. Lester RJG, Hayward CJ. Phylum Arthropoda. In Fish Diseases and Disorders, protozoan and metazoan infections, second ed. P.T.K. Woo, editor. CAB International, London, England. 2006; 1:466-565.

3. Shariff M, Kabata Z, Sommerville C. Host susceptibility to Lernaea cyprinacea $\mathrm{L}$. and its treatment in a large aquarium system. Journal of Fish Diseases. 1986; 12:393401.

4. Ishii S. Lernaeocera infesting the crucian carp. Dobutsugaku Zasshi (Zoological Magazine). 1915; 27:458-460. (In Japanese).

5. Harding JP. On some species of Lernaea. Bulletin of the British Museum (Natural History), Zoology. 1950; 1:327.

6. Grabda J. Life cycle and morphogenesis of Lernaea 
cyprinacea. Acta Parasitologica Polonica. 1963; 11:169198.

7. Kabata Z. Two new genera of the family Lernaeidae (Copepoda: Cyclopoida) parasitic on freshwater fishes of India. In Selected Papers on Crustacea Rabindranath Krishna Pillai Farewell Cmittee Trivandrum. 1983, 6976.

8. Wilson CB. Economic relations, anatomy, and life history of the genus Lernaea Bulletin of the United States Bureau of Fisheries. 1918; 35:163-195.

9. Demaree RS. Jr. Ecology and external morphology of Lernaea cyprinacea American Midland Naturalist. 1967; 78:416-427.

10. Kabata Z. Parasites and diseases of fish cultured in the tropics. Taylor and Francis, London, 1985.

11. Khalifa KA, Post G. Histopathological effect of Lernaea cyprinacea (Copepod parasite) on fish. Progressive Fish Culturist. 1976; 38(2):110-113.

12. Hoffman GL. Parasites of north American freshwater fishes. Comstock Publishing Associates, Itthaca and London. 1967, 539.

13. Tidd WM. Recent infestations of goldfish and carp by the 'anchor parasite,' Lernaea cyprinacea. Transactions of the American Fisheries Society. 1934; 64:176-180.

14. Hall DN. Occurrence of the copepod parasite Lernaea cyprinacea L., on the Australian grayling, Prototroctes maraena Gunther. Proceedings of the Royal Society of Victoria. 1983; 95:273-274.

15. Kennedy CR. Introductions, spread, and colonization of new localities by fish helminth and crustacean parasites in the British Isles: A perspective and appraisal. Journal of Fish Biology. 1993; 43:287-301.

16. Golder MI, Chandra KJ, Rahman AKA. Helminth parasitism in Nandus nandus (Hamilton). Bangladesh $\mathrm{J}$ Fish. 1987; 10:11-22.

17. Rahman AKA. A note on Argulus species which caused mortality in carps in the experimental cistern of the Freshwater research Station, Chandpur, East Pakistan. Pakistan J Sci Indust Res. 1968; 11:115-118.

18. Chandra KJ, Das AK, Alim MA, Barai AK. Lice (Argulus foliaceus ) on carp of Bangladesh Agricultural University experimental pond. Bangladesh Veterinan. 2004, 21, in press.

19. Hossain MMM, Rahman MZ, Islam MA, Alam ME, Rahman H. Lernaea (Anchor Worm) investigations in Fish. Int. J. Anim. Fish. Sci, 2013, 12-19

20. Brusca RG, Brusca. Invertebrates. Sunderland, Massachusetts: Sinauer Associates, Inc, 2003.

21. Baur O. Parasites of Freshwater Fish and the Biological Basis for their Control. Bulletin of the State Scientific Research Institute of Lake and River Fisheries. 1962; XLIX:108-112.

22. Kadhim RA, AL-Zubidy AB. Pathological effects of anchor worm Lernaea cyprinacea L. in common carp fishes Cyprinus carpio L. Journal of Babylon University, 2008.

23. Kabata Z. Parasites and diseases of fish cultured in the tropics. Taylor and Francis, London, 1985.

24. Hossain MD, Islam MA, Huq MM. Investigation into the parasitism of Bangladesh Agricultural University pond fishes. Bangladesh J Aquacult. 1978; 1:15-20. 